Whitworth Digital Commons

Whitworth University

Library Faculty Scholarship

Library

$7-2017$

\title{
From Service to Synergy: Embedding Librarians in a Digital Humanities Project
}

Janet Hauck

Whitworth University, jhauck@whitworth.edu

Follow this and additional works at: http:// digitalcommons.whitworth.edu/libraryfaculty

Part of the Library and Information Science Commons

\section{Recommended Citation}

Hauck, J. From service to synergy: Embedding librarians in a digital humanities project. College \& Undergraduate Libraries 24: 1, 1-18.

This Article is brought to you for free and open access by the Library at Whitworth University. It has been accepted for inclusion in Library Faculty Scholarship by an authorized administrator of Whitworth University. 


\title{
From Service to Synergy: Embedding Librarians in a Digital Humanities Project Janet E. Hauck \\ College \& Undergraduate Libraries, (2017) Vol. 24 Issue 1 \\ http://dx.doi.org/10.1080/10691316.2017.1341357
}

\begin{abstract}
Definitions of the term "digital humanities" vary, and its place in the academic library is still being explored. Yet exploration is indeed taking place, at large research institutions as well as, increasingly, at smaller colleges and undergraduate libraries. This article details an innovative digital humanities project carried out at an institution of 2,300 undergraduates, where a creative institutional partnership was the key to its success. The project has provided an outstanding opportunity to address the ACRL Framework for Information Literacy for Higher Education, while embracing the growing trend on many campuses to showcase student research.
\end{abstract}

\section{Keywords}

Digital humanities

Information literacy instruction

Institutional repositories

Librarian-faculty collaboration

Scholarly communication

\section{Introduction}

The advent and growth of the digital humanities has challenged many aspects of academic librarianship, yet many exciting opportunities have arisen within this burgeoning field. Academic librarians are discovering their roles in this landscape, and many are moving from a mindset of service to one of synergy. The use of the word synergy here denotes an effective partnership of two or more individuals where, as Aristotle so aptly stated: "the whole is greater than the sum of its parts." The author has experienced this exciting synergy as part of an innovative digital humanities project recently conducted at Whitworth University, a liberal arts institution of 2,300 undergraduates in Spokane, Washington. This article details practical strategies that can be implemented at many college and undergraduate libraries, and it draws upon familiar yet essential areas of professional practice, such as information literacy and scholarly communication. Librarians have long worked with users to empower them to conduct excellent research, and now they must continue this work as an integral part of the digital humanities conversation. Librarians are also becoming ever more equipped to provide avenues for showcasing this digital humanities scholarship, with the rapid addition of institutional repositories in many undergraduate libraries.

\section{Background}

One impetus for promoting the digital humanities in libraries is the growing desire in academia to showcase undergraduate student research. Academics want their students to become part of the past, present, and future scholarly discourse in any given field, and librarians recognize this as the ACRL frame of "Scholarship as Conversation." Interestingly, the practice of showcasing student research had its roots in the natural sciences, starting with the 1978 publication of the Directory on Undergraduate Research in Chemistry at Undergraduate Institutions. Then, in 1979, the first meeting of the Council on Undergraduate Research (CUR) was held, followed a 
few years later by CUR's 1985 National Conference on Undergraduate Research at Colgate University. The acronym NCUR was adopted for the conference, and this conference is still an important event in academia today. Undergraduate research in the social sciences was introduced to NCUR in 1993, and by 2008 the addition of research in the humanities was realized. This may be one reason that emphasis on the digital humanities appears to be a more recent phenomenon, and one that is gaining increased attention by undergraduate humanities faculty. Librarians must find avenues for partnering with these forward-thinking faculty members, in order to ensure that the very best research and scholarship is produced by their students.

Digital humanist Bethany Nowviskie expresses this concept well, strongly encouraging librarians to consider the digital humanities enterprise as an "organizational experiment in breaking away from shop-worn service relationships" (Nowviskie 2013, page 59). In other words, librarians are encouraged to contribute their skills to digital humanities projects as full partners, by doing what they already do quite well: providing resources for conducting excellent research, teaching users how to exploit these resources, and finally, assisting users in contributing their research to the scholarly conversation at large.

\section{Literature review}

The literature of three closely-related fields is reviewed here, in order to define the overlapping elements of digital humanities, information literacy instruction, and instructional technology that were present in the author's project. Each of these elements has its own history, and these histories have come together to create dynamic new opportunities for the digital humanities in undergraduate libraries. It is by incorporating these three elements that a digital humanities project will experience true synergy and partnership among its participants. This section will close with a review of literature that brings the digital humanities directly into academic libraries. The libraries described in the literature are primarily located at larger, well-staffed and well-funded institutions; yet, as the author's project will show, smaller undergraduate libraries can also accomplish digital humanities work when institutional partnerships are well utilized.

\section{Digital Humanities}

The term "digital humanities" has been aptly defined by Drucker as "work at the intersection of digital technology and the humanities disciplines." (Drucker 2013) This work includes a variety of activities, from the building of a digital library of scanned primary material to the creation and showcasing of secondary digital humanities content. The project that is the subject of this article was concerned with the latter. Historically speaking, it was the 1966 publication of the journal Computers and the Humanities that began to address significant research on the application of computing methods to a broad range of humanities scholarship. An examination of the ProQuest Library Science Database shows that, throughout the 1980s, the index term "humanities computing" was used when searching for the topic as it intersected with libraries.

The advent of the World Wide Web in 1993 was of course a pivotal moment for the digital humanities, and opportunities immediately opened for the development of digital libraries, collaborative work, publishing projects, and multimedia content. By the end of the 1990s, universities were establishing academic digital humanities programs, and, in 2005, the new index term, "digital humanities," appeared for the first time in the ProQuest Library Science Database. This new term retrieved the entire July/August 2005 issue of Library Technology Reports 
dedicated to the topic. That issue outlined the then-current landscape of this emerging field in specific relation to libraries. The editor identified publications, associations, conferences, tools, web portals, and, most importantly, innovative digital projects, especially those being curated at the Library of Congress. (Eden 2005)

\section{Information Literacy Instruction}

Information literacy instruction had its beginnings in the work of Patricia Knapp, who stated in a 1956 article that "it requires the planning of [library] learning experiences in accordance with recognized principles of learning; the co-operative efforts of the faculty must be enlisted in working through the processes involved." (Knapp 1956, page 226) Known over the years by such terms as "bibliographic instruction" and "course-integrated instruction," the process was fleshed out in the early 1970s by Earlham College librarians Evan Farber and James Kennedy, who wrote about Earlham's innovative library instruction program. Farber reflected on the ideal cooperative relationship between faculty and librarian by stating, "When that cooperative relationship works well, it can result in assignments that approach, if not reach, the ideal: where both the teacher's objectives and the librarian's objectives are not only achieved, but are mutually reinforcing." (Farber 1999, page 233) Kennedy reiterated the point when he said, "Such cooperation is essential." (Kennedy 1970, page 1452) By this time, the Library Orientation Exchange (LOEX) had also been founded at Eastern Michigan University, and heightened awareness of the collaboration necessary for information literacy instruction led to the establishment in 1977 of the Association of College and Research Libraries' Instruction Section.

The author has applied the method of course-integrated instruction for much of her career, and this was the instruction method utilized for the digital humanities project. Before the students entered the classroom for the first time, and continuously throughout the duration of the course, the goals and objectives of the professor were integrated with the expertise of the two librarians. This produced a true synergy and resulted in a successful experience for students, along with a polished and scholarly end product.

\section{Instructional Technology}

Technology has been applied to education since early in the twentieth century, when the motion picture projector was first used to show instructional films. World War II saw the development of overhead projectors, slide projectors, audio equipment, and simulators. In 1953, the journal Audio Visual Communication Review began publication, and television burst on the scene as a medium for delivering instruction. By the late 1970s, the advent of the microcomputer allowed for the incorporation of instructional variables like sequencing and feedback. (Reiser 1986)

Institutional repositories are an important part of this technological development, and there is interesting history here, as well. The advent and growth of institutional repositories for providing access to student and faculty research has an interesting history, as well. In this case, Wikipedia provides a succinct definition: "An institutional repository (IR) is an online archive for collecting, preserving, and disseminating digital copies of the intellectual output of an institution, particularly a research institution." Similar to the genesis of CUR and NCUR, the institutional repository had its beginnings in the natural sciences. Open archives for sharing scientific research were developed in pre-World Wide Web days, with ARPANET and BITNET among the most prominent. Soon after the arrival of the Web in 1993, MIT developed the DSpace 
software to store and disseminate its graduate theses and dissertations, and soon DSpace became an open-source software solution for other institutional repositories. The Open Archive Initiative, formulated in 1999, brought a surge in collaborative, open access efforts that have been growing ever since.

\section{Intersection of Digital Humanities and Libraries}

Two recent books stand out as works that illuminate the intersection of academic libraries and the digital humanities. In Digital Humanities in the Library: Challenges and Opportunities for Subject Specialists (Hartsell-Gundy, Braunstein, and Golomb 2015), each of the fourteen chapters describes digital humanities projects that took place at the writers' institutions and outlines skills that were needed and partnerships that were formed. Only one chapter described digital humanities efforts in a small college setting, with most efforts experiencing varying degrees of success. The writer noted, "The very collaboration that fosters DH work can also inhibit it at a small school; it is difficult to argue for dedicated staff in one area, in a place where most staff fill a number of roles" (Bell 2015, page 114). By utilizing Omeka software, the small college was able to produce various digital exhibits, but this author sees a distinct disadvantage to using open source products such as Omeka. The issues of sustainability and discoverability enter the picture, and the question of who will maintain these exhibits over time comes into play. At Whitworth, the use of bepress' (sic) Digital Commons as a hosted and supported product has assured sustainability over time.

It is clear that "Scholars, technologists, and humanities subject librarians each bring a unique approach: the scholar, content knowledge; the technologist, necessary technological skills; and the subject librarian, the overarching understanding of digital humanities research." (Gibson, Ladd, and Presnell 2015, page 7) If a smaller institution is able to identify, as the author did, a faculty member with content knowledge, an IR librarian with technological skills, and an instruction librarian with the knowledge and ability to teach subject-based research, that institution will be well on its way to successful digital humanities work.

A second book, Laying the Foundation: Digital Humanities in Academic Libraries, contains a section titled "Pedagogy and Instruction" (White and Gilbert 2016). In particular, Chapter 11 of this section asks a thought-provoking question that all academic librarians should consider, if they are contemplating involvement in the digital humanities. "Why should librarians get involved [in digital pedagogy]?" The writer provides his own answers by saying, "Librarians would do well to expand their concept of instruction to include the ability to find, evaluate, and learn to use new tools for exploring, sharing, reusing, and remixing research materials," and, "Becoming active partners in digital humanities pedagogy is clearly an extension of research instruction - the established domain of expertise for librarians within the academy." (Varner 2016, page 208)

The entire July/August 2013 issue of Journal of Library Administration is dedicated to digital humanities in libraries, making it almost another "book" on the subject. Articles such as Nowviskie's inspirational piece encouraging librarians to "engage as partners in the messy, ongoing, and unpredictable scholarly processes [of digital scholarship]" (Nowviskie 2013, page 55) and Sula's extensive table of "ALA Core Competencies of Librarianship Related to Digital Humanities" (Sula 2013, page 15) call upon academic librarians to begin DH work. Vandegrift 
and Varner (Vanderift and Varner 2013) provide a checklist outlining the process of forming institutional digital humanities partnerships, and Posner voices a mandate to library leaders to "give serious thought to the administrative and technical infrastructure that supports this work." (Posner 2013, page 44)

Several recent articles also discuss the intersection of digital humanities and libraries, making note of the partnerships involved. Wells, in his review of Digital Humanities in Practice, makes note of the fact that "digital humanities is a fundamentally collaborative activity which draws equally on expertise in humanities disciplines and information/communication technology," but he brings up the frequent pitfall of "the disjunction between the thinking of researchers from the two areas." (Wells 2013, page 258) Another article advocates for librarians to consider becoming "hybrid scholars" with expertise in both DH and LIS (Zhang, Liu, and Matthews 2015). All are encouraged to keep an open mind as they navigate these various partnerships. For up to the minute knowledge, a motivated librarian can keep up with or add to the conversation by following the ACRL Digital Humanities Group's blog site $d h+l i b$, "where the digital humanities and librarianship meet."

\section{Case Study \\ Institutional Synergy}

This section details a successful digital humanities partnership at Whitworth University, a liberal arts institution of 2,300 undergraduates. First, the development of the partnership will be outlined, including the interrelationships between librarians, classroom faculty, and students. A step-by-step recounting of the digital humanities project itself will follow, along with an assessment of the project. A brief discussion of project after-effects will close the section.

As mentioned, this project encompassed the overlapping elements of digital humanities, information literacy instruction, and instructional technology. The element of information literacy instruction was represented by the author, an 18-year member of the library faculty who has participated in library instruction for much of her time at Whitworth. The instructional technology element was filled by the institutional repository librarian, who was hired in 2015 to develop and promote services related to electronic and emerging technology, and to work toward the development of an institutional repository. The faculty member of the partnership has taught in the theology department at Whitworth for 16 years, and specializes in revival and conversion, having written a recent book on the $18^{\text {th }}$-century Scottish Evangelical Awakening. He has taught the History of Christian Renewal Movements course every year for the past decade, to a class of around 20 students each time it is offered.

Early in the spring of 2016 the author was approached by the theology professor mentioned above, with whom she had partnered numerous times on course-integrated information literacy instruction. Over the years, this faculty member has taken part in grant-funded projects regarding instruction in the use of primary and secondary sources, as well as a project that combined the virtue of "intellectual tenacity" and student research. Many conversations have taken place between the two about new resources and new ideas, so when the faculty member came with his latest new proposal, a synergistic partnership was ignited once again. 
This time the professor, who was preparing to teach his History of Christian Renewal Movements course again that spring, wanted his students to create a website of scholarly work that would document individual movements from the $16^{\text {th }}$ century to the present. He envisioned an online encyclopedia of sorts, to which new entries could be added by students every year the course was taught. The author recognized this as an opportunity to develop an innovative digital humanities project, along with an effective application of the ACRL frame "Information Creation as a Process." She immediately brought in her colleague, the newly-hired IR librarian, to form a three-way partnership. As the project gained definition, the professor placed the following description in his course syllabus:

"This semester our class will launch a new website currently in development called the Christian Movements Project. Each of you will belong to a research cohort of 4-5 classmates that will develop a page on the website that covers one of the centuries we will study. Each cohort will first determine - in consultation with me - the movements, events, persons, and topics to be included on their page. Each member of the cohort will then research, write, and submit an article (something akin to a 'research paper') on a particular topic, along with any audio and/or visual content that one might like to include. You will also receive some in-class coaching on research methods from one of our librarians, some guidance on digital resources from another librarian, and some project assistance by our T.A.s. By the end of the semester, the website and your pages should be successfully launched, pushed out to the internet search engines, and ready for the world to see! And, each of you who have submitted excellent (translated, 'A-level') work will have become a published author and contributor to the website. Go ahead... put that on your résumé!” (Beebe 2016, page 4)

Seasoned in collaborations with classroom faculty in course-integrated information literacy, the author was quick to ensure that this essential instruction step was included in the overall project plan. She was embedded early in the semester to provide instruction in using theological and other resources that would lead to successful research experiences for students. When surveyed at the semester's end, one student summed up what many others also reported: "I learned how to use databases to make research much easier!" An important new element for this digital humanities project was the mid-semester embedding of the institutional repository librarian. She taught students how to locate open access digital content to supplement their research, and then compiled the web version of the course's electronic encyclopedia using Wordpress.com. Student survey responses to her instruction were much like this one: "I never knew about all the copyright stuff before!” The website Christian Movements Project and the accompanying research articles are uploaded to the Whitworth Digital Commons site, and may be viewed at http://digitalcommons.whitworth.edu/th314h/.

\section{First Step}

Arguably, the first step in preparing for this project was the Whitworth Library's acquisition of bepress' (sic) Digital Commons institutional repository software. Several options were investigated, and the bepress product was chosen and purchased in fall 2015. It had been noted that many, if not most, undergraduate institutions of small-to-medium size had already acquired an IR or were in the process of doing so, and Whitworth wanted to do the same in a timely fashion. Once the software was installed, the new IR librarian began immediately to encourage populating of the repository with faculty scholarship, along with other unique and local content. 
After the digital humanities partnership was solidified, the first step in preparing for the project was the development of two library research guides using Springshare's LibGuides software (Figures 1 and 2.) The instruction librarian prepared the first guide to use early in the semester, and arranged for the professor to bring his students to the library for a hands-on session to gain experience with research resources. A stable URL for this guide allowed it to be linked to the class's course management software page for continued reference throughout the semester. The second guide was prepared by the IR librarian, and was introduced mid-semester as students were progressing on their research and beginning to seek digital content to use in their encyclopedia entries. A main feature of this guide is the information about rights-compliant digital objects and how to locate and use them. This proved to be knowledge that was needed and appreciated by most, if not all, of the students, demonstrating to them in a very tangible way the ACRL Frame of "Information has Value," which in this case was economic value.

[Figure 1 near here]

[Figure 2 near here]

\section{Next Steps}

The instruction librarian remained a source of one-on-one assistance throughout the semester, as students wrote their research articles. As they moved to the task of producing their encyclopedia entries for the website, the institutional repository librarian became more prominent, assisting students in locating and verifying their digital objects. The professor oversaw the quality of research and writing, suggesting edits or rewrites in order to assure that the work was worthy of showcasing via the Whitworth Digital Commons. Institutional repository policy states that any student's work must receive an "A" grade from a faculty member in order to be uploaded into the IR, proving the point of the ACRL frame that "Authority is Constructed and Contextual." In this case, the authority figure (professor) was actually the arbiter of what would be published, therefore assuring that material represented on the IR is of a high caliber. Figure 12 shows that being published on the Web became an extremely potent motivator for students to do well on the initial 2016 project.

Two types of end products were gathered from each student at the finish of the course: the lengthier research article and the shorter encyclopedia entry. The IR librarian utilized Wordpress.com to construct the encyclopedia website, then linked it to the Whitworth Digital Commons page developed for the course via a live click-able icon. The institutional repository was utilized in this way in order to take greatest advantage of the ability to showcase the research output of the university, and also to maximize discoverability of the students' work. Each entry is discoverable via search engines such as Google, by searching on the name of the student or the topic of the research paper (Figure 9). Control over and preservation of the work is also achieved, since bepress fully hosts and supports its repository software package and its users. Figures 3-9 depict screenshots of the various ways content from the students' articles may be accessed and viewed.

[Figure 3 near here] 
[Figure 4 near here]

[Figure 5 near here]

[Figure 6 near here]

[Figure 7 near here]

[Figure 8 near here]

[Figure 9 near here]

\section{Project Assessment}

An assessment of the digital humanities project was conducted at the end of the spring 2016 course, with three questions asked of the twenty-eight students:

1. "What did you learn from the research instruction you received early in the semester that was useful to you, or you had not known before?"

2. "What did you learn from the digital resources instruction you received mid-semester that was useful to you, or you had not known before?"

3. "What was the main thing that motivated you as you worked on and completed your part of this project?"

Responses to the questions were coded, and each question had three broad categories of response assigned to it. For example, Question 1 asked students about the research instruction they had received (Figure 10), and students gave answers such as: "I learned about the existence of the ATLA Database," and "I appreciated the research guide made especially for our class." These answers were categorized as resources available. Responses that indicated students learned about database utilization were: "I learned the intricate details of the ATLA Database," and "I liked learning how to make research much easier!" Finally, students' appreciation of learning search strategies was demonstrated by comments like: "I loved learning to narrow my search—going from thousands of articles to seven!" It is worth noting that the search strategies taught to students enabled them to succeed in the ACRL frame of "Searching as Strategic Exploration." Learning outcomes during this stage of the project were fairly evenly divided into the three broad categories.

Question 2 explored students' responses to the digital resources instruction they received midsemester (Figure 11). While a few students appreciated general searching tips in locating digital content ("I learned what sources our library has and how to find them") and in locating scholarly items ("this was so helpful in finding scholarly photos and videos"), the vast majority expressed a need to know how to determine copyright permissions for digital content. A full $80 \%$ of the students made statements such as, "I learned how to search for images that are legal to use," and "Now I know what pictures are public domain and what are off-limits." They also learned "how to add filters and license searches to Google Images," and generally "all about copyright stuff!"

Finally, Question 3 was posed to ascertain motivational factors for students, as they entered the realm of the digital humanities for the first time (Figure 12). Since student work must be 
approved by a faculty member before it can be uploaded into the institutional repository, the author and her partners wanted to know if this was an important factor for students. The answer was overwhelmingly affirmative, yet another potent motivator was present as well. Interestingly, students were strongly motivated by personal interest in the subjects of their research, as evidenced by these comments: "I was fascinated by the person I was researching," and "I wanted to do my research topic justice through my article." Several were honest about prescribed deadlines, indicating: "I appreciated due dates for steps along the way." Many, though, enthusiastically commented: "I enjoyed the idea that I might be published," and "I wanted to write a good enough paper for the website!"

[Figure 10 near here]

[Figure 11 near here]

[Figure 12 near here]

The same assessment questions were asked of students in the spring 2017 course, with very similar results. However, one additional question was posed by the professor, in which he asked students to list two or three of the most valuable things they had learned in the course overall. Answers to this question proved eye-opening, as they very clearly indicated the ways in which students experienced the ACRL frames throughout the semester-long project, even though the frames were not specifically named. See these listed below, along with the student comments that parallel them. The examination of this added question has provided confirmation to the author that her continual efforts to pursue partnerships with faculty in course-integrated information literacy are not only profitable, but essential as well.

\section{Authority is Constructed and Contextual}

- "I learned how to step back and look at Christianity from a wider perspective and more contextually."

- "I learned to look at modern revivals with discernment (by learning about past revivals.)"

\section{Information Creation as a Process}

- "I learned how to develop positions and be better able to support them."

- "I learned how to research well for papers and projects!"

\section{Information has Value}

- "This kind of work is very valuable and practical, as I want to be a well-educated leader (in the church.)"

- "It is important to see where your faith came from in order to see where it is going."

\section{Research as Inquiry}

- "I learned how to form thoughtful questions about historical readings."

- "I learned the importance of testing concepts, thoughts, and ideas to understand my beliefs concerning doctrine."

\section{Scholarship as Conversation}


- "I learned to synthesize the strengths of different perspectives."

- "I felt as if the stages, doubts, and questions the Christian church went through over centuries parallels what each person goes through personally over a lifetime."

\section{Searching as Strategic Exploration}

- "I had to consider perspectives I didn't necessarily agree with."

- "This class allowed me to see where I stood among different faith practices. My view actually changed!"

\section{After Effects}

One of the great advantages of using bepress' Digital Commons software for an institutional repository is the support provided in the form of monthly usage reports. The Christian Movements Project website and student research articles were uploaded into the IR at the beginning of October 2016, and from that time through the end of January 2017 when the first trimester analytics were run, there had already been a total of 147 individual downloads! A graph of these downloads is one feature of the usage report (Figure 13), showing a high of 52 downloads in January 2017 alone. A number of other views of the data are provided, and one of the most compelling for the student authors is a global map of readership distribution (Figure 14). Another view lists the individual institutions that are downloading material, along with titles of the research articles being utilized. Here are just a few examples:

- Brigham Young University, Provo, UT - "Corrie Ten Boom: God's Tumbleweed"

- St. Paul's Grammar School, Penrith, Australia - "The Impact of Justification by Faith on Luther's Preaching"

- College Edouard Montpetit, Quebec City, Canada - "A Brief Overview of the Puritan Movement"

- University of South Florida, Tampa, FL - "Dietrich Bonhoeffer: Christian. Pacifist. Assassin?"

- Northwest University, Kirkland, WA - "Allegory? Myth? Lewis' Narnian Series Exposed"

- Liberty University, Lynchburg, VA - "Jacob Arminius: The Humble Reformer and his Theology"

[Figure 13 near here]

[Figure 14 near here]

This past spring, it was gratifying to have the same theology professor indicate his desire to reactivate the digital humanities partnership for his 2017 History of Christian Renewal Movements course, in order to continue meeting the goal of having students add new entries to the Christian Movements Project website and to the Whitworth Digital Commons institutional repository. This second round of the project has just been completed, and there is full anticipation that a third round will be undertaken sometime in 2018. Meanwhile, other digital humanities partnerships are in the works at Whitworth, and the project described in this article provides a successful model on which to pattern exciting and innovative new digital humanities projects.

\section{Conclusion}


This article has shown that it is possible to carry out digital humanities projects at smaller academic institutions, when the right partnerships are formed, and the best resources are employed. Librarians who have been adept at forming collaborative relationships with classroom faculty have only to continue building on these synergistic partnerships in order to advance to the next stage of active digital humanities work. With the addition on many smaller campuses of an institutional repository, there exists a sustainable space for showcasing and managing these digital projects. It is both thrilling and beneficial to students at all types of institutions when they are able to make a contribution to the world's scholarly conversation.

In summary, this innovative project has provided an outstanding opportunity to address the ACRL Framework for Information Literacy for Higher Education while embracing the growing trend on many campuses to showcase student research. As more academic libraries add institutional repositories to their scholarly resources and seek to partner in new ways with faculty and undergraduates, projects like this one may prove to be a vitally effective method of catapulting librarianship into the digital humanities world.

\section{References}

Beebe, Keith. 2016. "TH-314: History of Christian Renewal Movements, Spring 2016." Course Syllabus. Whitworth University, Spokane, WA.

Bell, Christina. 2015. "In Practice and Pedagogy: Digital Humanities in a Small College Environment." In Digital Humanities in the Library: Challenges and Opportunities for Subject Specialists, edited by Hartsell-Gundy, Arianne, Laura Braunstein, and Liorah Golomb, 103-26. [Chicago, IL:] ACRL.

Drucker, Johanna. 2013. http://dh101.humanities.ucla.edu/?page_id=13.

Eden, Brad. 2005. Library Technology Reports 41(4): 7-44.

Farber, Evan. 1999. "Faculty-Librarian Cooperation: A Personal Retrospective." Reference Services Review 27(3): 229-34.

Gibson, Katie, Marcus Ladd, and Jenny Presnell. 2015. "Traversing the Gap: Subject Specialists Connecting Humanities Resarchers and Digital Scholarship Centers." In Digital Humanities in the Library: Challenges and Opportunities for Subject Specialists, edited by Hartsell-Gundy, Arianne, Laura Braunstein, and Liorah Golomb, 3-17. [Chicago, IL:] ACRL.

Hartsell-Gundy, Arianne, Laura Braunstein, and Liorah Golomb, editors. 2015. Digital Humanities in the Library: Challenges and Opportunities for Subject Specialists. [Chicago, IL:] ACRL.

Kennedy, James R., Jr. 1970. “Integrated Library Instruction.” Library Journal 95(8): 1450-3.

Knapp, Patricia B. 1956. "A Suggested Program of College Instruction in the Use of the Library." The Library Quarterly 26 (3): 224-31. 
Nowviskie, Bethany. 2013. "Skunks in the Library: A Path to Production for Scholarly R\&D." Journal of Library Administration 53(1): 53-66.

Posner, Miriam. 2013. "No Half Measures: Overcoming Common Challenges to Doing Digital Humanities in the Library." Journal of Library Administration 53(1): 43-52.

Reiser, Robert A. 1986. "Instructional Technology: A History." In Instruction Technology: Foundations, edited by Robert Gagne, 11-48. Mahwah, NJ: Lawrence Erlbaum Assoc.

Schreibman, Susan, Ray Siemens, and John Unsworth, editors. 2004. A Companion to Digital Humanities. Oxford: Blackwell.

Schreibman, Susan, Ray Siemens, and John Unsworth, editors. 2016. A New Companion to Digital Humanities. [Oxford:] Wiley-Blackwell.

Sula, Chris Alen. 2013. "Digital Humanities and Libraries: A Conceptual Model." Journal of Library Administration 53(1): 10-26.

Vandegrift, Micah, and Stewart Varner. 2013. "Evolving in Common: Creating Mutually Supportive Relationships between Libraries and the Digital Humanities." Journal of Library Administration 53(1): 67-78.

Varner, Stewart. 2016. "Library Instruction for Digital Humanities: Pedagogy in Undergraduate Classes." In Laying the Foundation: Digital Humanities in Academic Libraries, edited by John W. White and Heather Gilbert, 205-20. West Lafayette, IN: Purdue University Press.

Wells, David. 2013. Review of Digital Humanities in Practice, edited by Claire Warwick, Melissa Terras, and Julianne Nyhan. Australian Academic and Research Libraries 44(4): 258-9.

White, John W., and Heather Gilbert, editors. 2016. Laying the Foundation: Digital Humanities in Academic Libraries. West Lafayette, IN: Purdue University Press.

Zhang, Ying, Shu Liu, and Emilee Mathews. 2015. "Convergence of Digital Humanities and Digital Libraries.” Library Management 36(4/5): 362-77. 